WARSZTATY Z GEOGRAFII TURYZMU

ISBN 978-83-7969-138-8 $\quad$ s. 107-120

http://dx.doi.org/10.18778/7969-138-8.08

Barbara PISARSKA

Akademia Finansów i Biznesu Vistula w Warszawie

\title{
ZMIANY STATUSU, ZARZĄDZANIA, INFRASTRUKTURY I RUCHU WCZASOWICZÓW FWP
}

\section{Okoliczności powołania FWP w 1949 r. i zmiany jego statusu w 1997 r.}

Zgodnie z ideologią ustroju socjalistycznego coraz większą rolę odgrywać miały wczasy pracownicze. Najpierw ich organizatorem była Komisja Centralna Związków Zawodowych (KCZZ), a od kwietnia 1945 r. Wydział Wczasów Centralnej Rady Związków Zawodowych (CRZZ), za sprawą którego poszczególne związki przejmowały obiekty wypoczynkowe, głównie na Ziemiach Odzyskanych. Jak zaznaczyli D. JAROsz (2001, s. 482) i R. OKRASA (1980, s. 4-5) - ujemnymi stronami braku centralizacji akcji wczasowej były:

- administrowanie 624 obiektami położonymi w 112 miejscowościach przez 200 różnych instytucji, zakładów pracy, urzędów i związków zawodowych;

- brak planowania, co skutkowało zachwianiem proporcji między liczbą gości (3-4 osoby) a liczbą personelu (10-15 osób) w niektórych obiektach;

- zbyt duże zróżnicowanie w zakresie wyposażenia ośrodków i wyżywienia gości. 
Ustawa Sejmu z 4 lutego 1949 r. przekształciła wymieniony Wydział Wczasów CRZZ w Fundusz Wczasów Pracowniczych (FWP), nadając mu osobowość prawną prawa publicznego i rangę głównego ośrodka dyspozycyjnego (KULCZYCKI 1970, s. 176, OKRASA 1980, s. 7). Jak podkreślili Z. PRONIEWICZ, W. SOSZYŃSKI (1959, s. 35) - olbrzymi majątek należący głównie do Państwa i związków zawodowych został oddany w zarząd i użytkowanie FWP; tylko nieliczne obiekty były własnością Funduszu albo osób prywatnych.

Według Uchwały Sekretariatu CRZZ z 1950 r. zadaniem FWP było „organizowanie i umożliwienie wypoczynku związkowcom, w pierwszej kolejności przodownikom pracy, racjonalizatorom, nowatorom i mistrzom oszczędności oraz umożliwienie odnowienia sił robotników zatrudnionych przy ciężkich i wyczerpujących pracach..." (JAROSZ 2001, s. 482). Brano również pod uwagę zasłużonych dla zakładu emerytów i rencistów z rodzinami, pracowników z długim stażem pracy, z dużymi rodzinami oraz tych, którzy wychowywali dzieci samotnie, szczególnie gdy dochody na jedną osobę były stosunkowo niskie (LIBICKI 1980, s. 64).

Określenie tak szerokiego grona uprzywilejowanych znalazło potwierdzenie w artykule 69 Konstytucji PRL z 1952 r. (Konstytucja... 1989). Ustanowiono go, zakładając słusznie, że realizacja prawa „ludu pracującego miast i wsi" do wypoczynku przyczyni się do podniesienia poziomu zdrowia i kultury duchowej narodu, głównie w wyniku upowszechniania kultury czasu wolnego poprzez obcowanie z przyrodą, zabytkami, muzyką, prasą i książkami (JAROSZ 2003, s. 20-22). W ten sposób wdrażano w życie zasady sprawiedliwości społecznej, a to właśnie stanowiło istotę działalności socjalnej, którą na szerszą skalę podją PPS - jeszcze przed odzyskaniem niepodległości w 1918 r. (PISARSKA 2011, s. 177).

W 1957 r. zrezygnowano z monopolistycznego charakteru działalności Funduszu, dając szerokie możliwości inicjatywom zakładów pracy i związków zawodowych w zakresie budowy nowych obiektów wypoczynkowych. Ich boom, szczególnie w latach 1970-1977, był kontynuacją realizacji troski o warunki wypoczynku dla ludzi pracy wyrażonej w dokumentach państwowych od 1969 r. do 1979 r. (PISARSKA 2011, s. 178, 181).

Dyrekcja Naczelna (DN) Funduszu administrowała domami wczasowymi za pośrednictwem czterech dyrekcji okręgowych, a od 1955 r. poprzez Zarządy Okręgów Wczasowych (ZOW - ich liczba zmieniała się od 20 do 13). Centralizacja zarządzania znalazła odbicie także w systemie rozprowadzania skierowań wczasowych. Od 1952 r. przy DN istniało Centralne Biuro 
Skierowań (CBS), któremu podlegało 17 wojewódzkich (WBS) oraz 306-300, a od 1957 r. - 27 powiatowych biur skierowań (PBS), które łącznie przekształcono w 17 Okręgowych Biur Sprzedaży w związku z reformą administracyjną z 1975 r. (OKRASA 1980, s. 8, 12, 15, 24, 30, PRONIEWICZ, SOSZYŃSKI 1959, s. 56-58). Do Biur Sprzedaży zgłaszały się poszczególne zakłady pracy lub pojedynczy pracownicy. Opłacali oni koszty, które obliczano w zależności od ich zarobków. Kwoty brakujące do pokrycia pełnych kosztów pobytu pokrywał FWP, któremu przyznawano na ten cel - corocznie dotacje z budżetu państwa. Ponadto wczasowicze otrzymywali bezpłatne bilety powrotne, których koszt rozliczany był pomiędzy FWP a Ministerstwem Komunikacji (KULCZYCKI 1970, s. 176).

Władze FWP były zobowiązane do gospodarowania majątkiem i jego ochrony. Ustawa z 21.04.1988 r. o Funduszu Wczasów Pracowniczych przekształciła go w jednostkę organizacyjną Ogólnopolskiego Porozumienia Związków Zawodowych (OPZZ). Pomimo że OPZZ nie uzyskało w ówczesnym stanie prawnym statusu właściciela majątku FWP, to przekazało go utworzonej przez siebie w dniu 25.07.1997 r. spółce FWP Sp. z o.o. Trybunał Konstytucyjny wydał orzeczenie wskazujące na niezgodność z Konstytucją przepisów, które posłużyły do przejęcia majątku FWP; powinien on być do dyspozycji Skarbu Państwa. W dniu 12.06.2001 r. OPZZ utworzyło Fundację „Porozumienie”, której przekazało w postaci darowizny całość swoich udziałów, co zostało ocenione przez NIK jako pozbawione podstawy prawnej. Niestety, kolejni ministrowie właściwi do spraw pracy oraz skarbu państwa nie podjęli skutecznych działań zaradczych (Informacja.., 2004, s. 2-30). Obiekty FWP były remontowane, modernizowane, budowane za pieniądze ludzi pracy, więc władze nie powinny mieć wątpliwości, że należało utrzymać status FWP jako agendy związków zawodowych, albo nawet go wzmocnić, podnosząc do rangi agendy państwowej.

W 2013 r. klient mógł kupić skierowanie w wybranym domu wczasowym FWP Sp. z o.o. albo w 15 punktach sprzedaży, które zlokalizowane były w ośmiu miastach: w Warszawie (w pięciu punktach), we Wrocławiu (w trzech), w Poznaniu (w dwóch) oraz po jednym w Łodzi, Lublinie, Krakowie, Opolu i Legnicy. W przypadku sprzedaży internetowej klient otrzymywał rabat (5\%), opłacał skierowanie kartą płatniczą i odbierał je po przybyciu do domu wczasowego. Pełne informacje o ofercie zamieszczono w folderach dostępnych w punktach sprzedaży oraz na stronie internetowej Spółki, gdzie podano adresy tychże punktów. 


\section{Zmiany $w$ infrastrukturze FWP}

Autorka przestudiowała dostępne materiały statystyczne od 1949 do $1990 \mathrm{r}$. - jako ostatniego, dla którego w roczniku wyodrębniono FWP. W tab. 1 z powodu ograniczeń edytorskich wybrano tylko takie 24 lata spośród 42 lat z podanego okresu, które odzwierciedlają charakter rozwoju FWP. Ponadto wzięto pod uwagę ostatnie trzy lata odnoszące się do FWP Sp. z o.o. w celu uwypuklenia zmian wielkości: bazy i ruchu wczasowego.

Tabela 1. Wielkość bazy i ruchu wczasowego FWP oraz ich udziały na tle kraju

\begin{tabular}{|l|c|c|c|c|c|c|}
\hline \multirow{2}{*}{ Rok } & \multicolumn{2}{|c|}{ Miejsca noclegowe FWP } & \multicolumn{2}{|c|}{ Osoby korzystające z FWP } & \multicolumn{2}{|c|}{ Osobodni FWP } \\
\cline { 2 - 7 } & w tys. & $\begin{array}{c}\text { \% bazy wcza- } \\
\text { sowej kraju }\end{array}$ & w tys. & $\begin{array}{c}\text { \% ruchu wczasowego } \\
\text { kraju }\end{array}$ & w mln & $\begin{array}{c}\text { \% ruchu wcza- } \\
\text { sowego kraju }\end{array}$ \\
\hline 1949 & 35,6 & - & 435,0 & - & - & - \\
\hline 1951 & 38,5 & - & 527,0 & - & 7,2 & - \\
\hline 1952 & 33,5 & - & 403,2 & - & 5,6 & - \\
\hline 1956 & 37,4 & - & 399,3 & 85,9 & 6,4 & - \\
\hline 1958 & 35,1 & - & 447,1 & 89,0 & 6,5 & - \\
\hline 1960 & 36,0 & $\mathbf{4 7 , 4}$ & 431,7 & 89,4 & 6,5 & 62,4 \\
\hline 1962 & 42,2 & 41,3 & 484,3 & 74,5 & 7,2 & 58,2 \\
\hline 1966 & 49,4 & 24,6 & 577,0 & 51,7 & 8,6 & 42,5 \\
\hline 1967 & 53,4 & 20,9 & 583,6 & 50,1 & 8,8 & 38,3 \\
\hline 1969 & 56,9 & 19,3 & 644,2 & 31,0 & 9,7 & 33,1 \\
\hline 1970 & 56,0 & 17,5 & 628,3 & 29,0 & 10,0 & 32,1 \\
\hline 1971 & 58,3 & 16,2 & 662,3 & 24,3 & 9,6 & - \\
\hline 1972 & 58,7 & 15,1 & 672,0 & 23,8 & 9,7 & - \\
\hline 1973 & 56,3 & 13,9 & 706,7 & 23,8 & - & - \\
\hline 1974 & 53,2 & 10,8 & 615,9 & 18,1 & - & - \\
\hline 1976 & 47,1 & 8,8 & 622,5 & 14,4 & 8,9 & 16,5 \\
\hline 1978 & 46,5 & 8,4 & 589,4 & 13,2 & 8,5 & 15,6 \\
\hline 1979 & 48,0 & 9,0 & 602,7 & 13,7 & 8,5 & 16,1 \\
\hline 1981 & 44,0 & 8,6 & 494,0 & 13,1 & 7,2 & 15,3 \\
\hline 1982 & 38,7 & 8,2 & 365,0 & 11,8 & 5,3 & 14,3 \\
\hline 1985 & 36,0 & 7,2 & 408,0 & 10,7 & 5,5 & 13,1 \\
\hline 1987 & 35,4 & 7,1 & 430,0 & 10,8 & 5,6 & 13,4 \\
\hline 1989 & 32,6 & 6,8 & 400,0 & 10,4 & 5,5 & 13,4 \\
\hline 1990 & 27,6 & 6,7 & 229,0 & 8,4 & 2,9 & 10,6 \\
\hline 2010 & 3,6 & - & - & - & - & - \\
\hline 2011 & 3,4 & - & 23,6 & - & - & - \\
\hline 2012 & 3,2 & - & 30,9 & - & - & - \\
\hline & & & & & & \\
\hline
\end{tabular}

Źródła: dane i obliczenia własne na podstawie: Roczniki statystyczne GUS 1950-1991, Warszawa; Statystyka turystyki... (1967); Turystyka 1973; dane Zarządu FWP Sp. z o.o. za lata 2010-2012.

Objaśnienia: czcionką pogrubioną zaznaczono maksymalne (wśród dostępnych) wartości określonych wskaźników; - brak danych oraz brak płaszczyzn odniesienia do obliczenia udziałów\% FWP i FWP Sp. z o.o. na tle kraju. 
Z tab. 1 wynika, że liczba użytkowanych miejsc noclegowych stopniowo wzrastała w pierwszych trzech latach działalności FWP do 38,5 tys., po czym w 1952 r. nastąpił duży spadek o 4,7 tys. Najprawdopodobniej wynikał on z konieczności wycofania wielu obiektów z eksploatacji ze względu na stan techniczny. W następnych czterech latach (do 1956 r.) wielkość bazy noclegowej znowu wzrosła, zapewne na skutek wyremontowania domów wczasowych najbardziej tego wymagających. Później tendencja wzrostowa utrzymywała się nieprzerwanie w latach 1959-1969 (rys. 1).

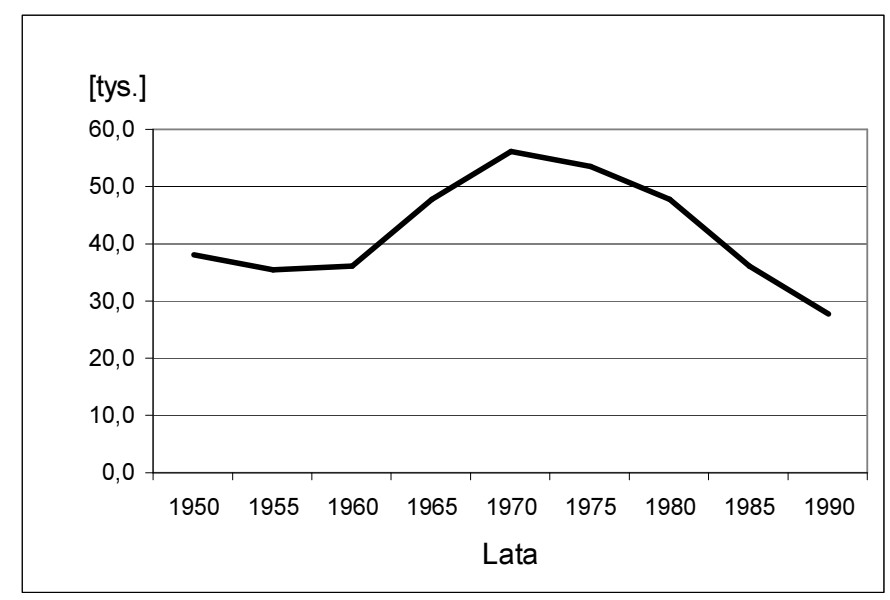

Rys. 1. Liczba miejsc noclegowych FWP w latach 1950-1990

Źródło: opracowanie własne

Na początku lat 70. nastąpiły spore fluktuacje: lekki spadek w 1970 r. do 56 tys., a potem wzrost o 2,3 tys. w 1971 r. i o 0,4 tys. w 1972 r. - do 58,7 tys., co okazało się maksymalną wielkością w całym okresie działalności FWP. Od 1973 r. zaczął się okres z przewagą skokowych spadków (w 1973 r. o 2,4 tys., w 1974 o 3,1 tys., w 1976 r. o 6,6 tys., w 1978 r. o 1,3 tys. miejsc), co w części wynikało z postawienia - jeszcze wyraźniej niż wcześniej - na rozwój wczasowej bazy zakładowej (niektóre obiekty FWP odstąpiono konkretnym zakładom pracy). Tendencja spadkowa utrzymała się w latach 80 .: w 1981 r. baza noclegowa zmniejszyła się o 3,8 tys., a w 1982 r. aż o 5,3 tys. miejsc, co mogło wiązać się z przejściem pod zarząd organów administracji państwowej $\mathrm{w}$ czasie stanu wojennego. Kolejne straty miejsc nastąpiły w 1985 r. (o 2,4 tys.), 1987 r. (o 0,9 tys.), 1989 r. (o 2,3 tys.) oraz w 1990 r. (aż 
o 5 tys.). Jak wspomniano, roczniki statystyczne GUS, począwszy od $1992 \mathrm{r}$. nie zawierały już wyszczególnienia FWP, chociaż zmiana jego statusu prawnego nastąpiła dopiero w $1997 \mathrm{r}$.

W celu ukazania rangi bazy Funduszu prześledzono udział jego miejsc noclegowych w bazie wczasowej całego kraju. Było to możliwe dla lat 19601990, dla których w rocznikach GUS, począwszy od $1961 \mathrm{r}$. podano potrzebne do wyliczenia tego wskaźnika informacje (tab. 1). Udział ten w $1960 \mathrm{r}$. wynosił 47,4\%; wcześniej był najprawdopodobniej wyższy, a systematycznie malał od początku wymienionego wcześniej okresu, pomimo wzrostu liczby miejsc noclegowych FWP w latach 1958-1972. Wynikało to głównie z dynamicznego rozwoju liczby miejsc wczasowych w bazie zakładowej, szczególnie od końca lat 60., kiedy udział FWP zszedł poniżej 20\%, a potem od połowy lat 70., kiedy spadł poniżej 10\% (PISARSKA 2011, s. 179-180, 205). W roku 1990 wskaźnik ten wynosił 6,7\%. W rocznikach statystycznych GUS, począwszy od 1992 r., nie wyodrębniano już obiektów wczasowych, w tym FWP; tabela zatytułowana była „Baza noclegowa turystyki”, co z dzisiejszej perspektywy można ocenić jako zabieg zbieżny z zamysłem likwidacji wypoczynku socjalnego poprzez tzw. prywatyzację obiektów jeszcze wtedy jemu służących, które stały się później ogólnodostępne.

W 2010 r. liczba ogólnodostępnych miejsc noclegowych FWP Spółki z o.o. wynosiła 3629, w 2011 r. - 3449, w 2012 r. - 3157, a więc nadal występuje tendencja spadkowa. Pomimo dużej różnicy wielkości bazy - w przeszłości i obecnie, warto poznać jej strukturę przestrzenną, przedstawioną $\mathrm{w}$ tab. 2. Pokazuje ona pogłębienie biegunowości, wyrażającej się zwiększeniem udziałów bazy noclegowej zlokalizowanej w strefach: górskiej (o 10,3\%) oraz nadmorskiej (o 3\%). Dodać należy, że najwięcej miejsc pozostało w Polsce południowo-zachodniej (40,2\%) i północno-zachodniej (29,1\%). W dwóch miejscowościach karpackich (Zakopanem i Krynicy) skupia się 21,5\% miejsc, a w Rucianem Nida i w Spale łącznie 9,2\%.

W latach 1961-1966 baza wczasowa FWP była zlokalizowana w 116 miejscowościach, czyli w ponad 1/3 spośród wszystkich 373 z funkcją wczasową w kraju (Związkowe... 1967), co świadczy o dużym rozprzestrzenieniu tej bazy w przeszłości. W 2013 r. 30 obiektów znajdowało się w 13 miejscowościach.

FWP zawsze dbał o standard swoich ośrodków (Związkowe... 1967 s. 1-2). Obecnie również baza noclegowa Spółki mieści się na ogół w zmodernizowanych trwałych obiektach, z których 14 było w posiadaniu FWP od 1958 r.; stwierdzono to na podstawie dokładnego rejestru budynków zamieszczo- 
nego w opracowaniu Z. PRONIEWICZA i S. SOSZYŃSKIEGO (1959, s. 42-49). Z tab. 3 wynika, że obecnie standard obiektów Spółki jest wyrównany - w końcu 2011 r. w strukturze miejsc noclegowych dominowały obiekty z kategorią I (61,6\%) i II (34\%).

Tabela 2. Struktura przestrzenna bazy noclegowej FWP i FWP Sp. z o.o. w latach 1975 i 2012

\begin{tabular}{|l|r|r|}
\hline \multirow{2}{*}{\begin{tabular}{c}
\multirow{2}{*}{$\begin{array}{c}\text { Strefa } \\
\text { krajobrazowa }\end{array}$} \\
\cline { 2 - 3 }
\end{tabular}} & \multicolumn{2}{|c|}{ Rok } \\
\cline { 2 - 3 } & \multicolumn{2}{|c|}{ w \% } \\
\hline Morze & 26,1 & 2012 \\
\hline Niziny & 22,5 & 29,1 \\
\hline Góry & 51,4 & 9,2 \\
\hline Razem & 100,0 & 61,7 \\
\hline
\end{tabular}

Źródła: R. OKRASA (1976) oraz obliczenia własne na podstawie danych Zarządu FWP Sp. z o.o. za rok 2012.

Tabela 3. Standard bazy noclegowej FWP Sp. z o.o. w 2012 r.

\begin{tabular}{|l|c|}
\hline \multicolumn{1}{|c|}{ Kategoria } & Odsetek \\
\hline Apartamenty & 3,3 \\
\hline I & 63,8 \\
\hline II & 31,6 \\
\hline III & 1,2 \\
\hline IV & 0,1 \\
\hline
\end{tabular}

Źródło: obliczenia własne na podstawie danych Zarządu FWP Sp. z o.o.

Większość obiektów noclegowych posiada własne restauracje, które w przeszłości odgrywały rolę jadłodajni (stołówek) serwujących na ogół dwa zestawy obiadowe do wyboru. W kilku obiektach funkcjonują kawiarnie i mini-bary. Większość ośrodków posiada świetlice. Niektóre obiekty, tak jak np. Ośrodek Wczasowo-Rehabilitacyjny „Ziemowit” w Jarnołtówku w Górach Opawskich, dysponują salami konferencyjnymi.

Infrastruktura do rekreacji na wolnym powietrzu, jak i w pomieszczeniach jest raczej - podobnie jak w przeszłości - skąpa i mało zróżnicowana (miejsca na ognisko, stoły do tenisa, ping-ponga albo bilardu). Wyjątek stanowi wymieniony "Ziemowit”, w którym znajduje się boisko do siatkówki 
i kort tenisowy. Największy zakres usług rekreacyjnych wewnątrz budynków oferują trzy obiekty: "Ziemowit”, „Hyrny” w Zakopanem oraz „Albatros" w Mielnie (baseny, sale do ćwiczen, sauny, gabinety fizjoterapeutyczne).

\section{Zmiany w ruchu wczasowym FWP}

Z informacji zawartych w tab. 1 oraz na rys. 2 wynika, że w 1949 r. z obiektów FWP skorzystało 435 tys. osób. Ich liczba wzrosła w 1950 r. do 554 tys. (tę wartość uznaję za $100 \% \mathrm{w}$ pierwszym pełnym roku działalności), a w roku 1952 spadła do 403,2 tys. osób (czyli do 72,7\%), co znalazło trochę słabsze (bo turnusy 2-4-tygodniowe) odzwierciedlenie w liczbie udzielonych noclegów (spadek do 78,4\% - z 7,2 mln do 5,6 mln). Od 1952 r. liczba osób korzystających, a szczególnie liczba udzielonych noclegów generalnie (bo z wyjątkiem 1956 r.) rosła, nie osiągając jednak długo pułapów z 1950 r. - 554 tys.; odnośnie do pierwszego z tych wskaźników nastąpiło to w 1966 r. - 577 tys., a w przypadku drugiego, w 1962 r. - 7,2 mln. W wyniku decyzji z 1957 r. o decentralizacji organizacji wczasów - już w 1965 r. udział FWP pod względem liczby udzielonych noclegów wyniósł poniżej 50\% (48,5\%); pod względem liczby wczasowiczów dopiero w 1968 r. - 44,7\%.

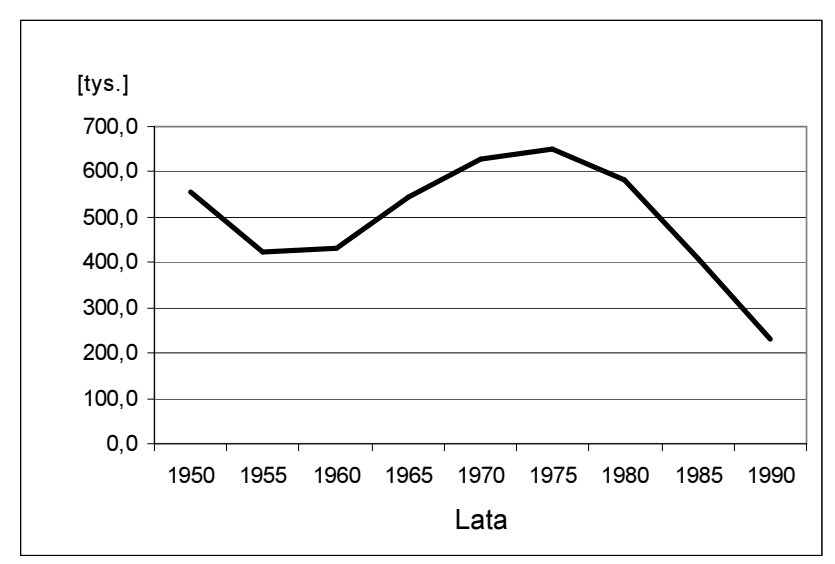

Rys. 2. Liczba wczasowiczów FWP w latach 1950-1990

Źródło: obliczenia własne 
W związku z dobrze prowadzoną ewidencją możliwa była charakterystyka ruchu wczasowego. Tabela 4 ukazuje strukturę rodzajową wczasowiczów. Na ogólną liczbę 4,7 mln wczasowiczów obsłużonych przez FWP w pierwszym 10-leciu - największy udział mieli uczestnicy wczasów „zwykłych" (wypoczynkowych) (80\%) oraz wczasów leczniczych 21- dniowych $(11,3 \%)$.

Tabela 4. Struktura rodzajowa wczasów FWP w 10-leciu 1949-1958

\begin{tabular}{|l|c|c|}
\hline \multicolumn{1}{|c|}{ Wczasy } & $\begin{array}{c}\text { Liczba } \\
\text { wczasowiczów } \\
\text { w tys. }\end{array}$ & Odsetek \\
\hline Ogółem & 4701,5 & 100,0 \\
\hline Wypoczynkowe 14, 10- i 7-dniowe & 3766,4 & 80,0 \\
\hline Lecznicze 21-dniowe & 528,0 & 11,3 \\
\hline Turystyczne & 137,7 & 2,9 \\
\hline Rodzinne & 120,7 & 2,6 \\
\hline Lecznicze 28-dniowe & 79,3 & 1,7 \\
\hline Matek z dziećmi & 69,4 & 1,5 \\
\hline
\end{tabular}

Źródło: Z. PRONIEWICZ, W. SOSZYŃSKI (1959, s. 11).

Odpowiednio do tychże proporcji kształtował się przebieg linii rozwoju poszczególnych rodzajów wczasów w omawianym okresie. Na najwyższym pułapie - ale nierówno - przebiegał rozwój wczasów wypoczynkowych, a najbardziej systematyczny wzrost dotyczył wczasów leczniczych 21-dniowych oraz wczasów dla matek z dziećmi (ten ostatni na najniższym poziomie frekwencji) (tabelę i wykres charakteryzujące te zjawiska przedstawili w swym opracowaniu Z. PRONIEWICZ, W. SOSZYŃSKI 1959, s. 12).

W końcu pierwszego 10-lecia działalności FWP, tzn. w 1958 r. - najwyższe, zarówno podaż miejsc, jak ich wykorzystanie (w nawiasach podano jego stopień), dotyczyły takich ZOW, jak: Polanica (83,9\%), Mikuszowice (88,1\%), Zakopane (87\%), Szklarska Poręba (76,6\%), Krynica Z. (98,5\%), Karpacz (69,5\%), Lądek (92,3\%), Rewal (97,7\%), Cieplice (69,3\%) oraz Międzyzdroje (97,5\%) (na podstawie: PRONIEWICZ, SOSZYŃSKI 1959, s. 27).

W omawianym okresie, w skali roku, najwięcej osób korzystało z wczasów FWP w lipcu i sierpniu (razem 37,4\%), a od czerwca do września (włącznie) - 62,2\%; najmniej $\mathrm{w}$ listopadzie $\mathrm{i} w \mathrm{kwietniu}$. Warto dodać, że średnia liczba wczasodni w roku na 1 miejsce wynosiła w tym pierwszym 10-leciu 183. Najwyższe wartości tego wskaźnika charakteryzowały wczasy miejskie 
w stolicy (siedem dni dla ludzi z małych miejscowości) - 299 dni, 28-dniowe wczasy lecznicze (przeciwgruźlicze) - 269,1 dni oraz 21-dniowe lecznicze 248,2 dni (PRONIEWICZ, SOSZYŃSKI 1959, s. 26, 30).

Na początku drugiego 10-lecia przebieg linii rozwoju ruchu wczasowiczów jakby powtórzył się; najpierw był wzrost, potem spadek i znowu - od 1961 r. systematyczny wzrost do 1969 r. (644,2 tys. osób korzystających oraz 9,7 mln udzielonych noclegów) (tab. 1). W latach 70. i 80. liczba wczasowiczów ulegała fluktuacjom z przewagą tendencji spadkowej; większe skoki w dół miały miejsce w latach: 1974, 1978 (długotrwałe deszcze latem), 19811982 (stan wojenny), 1985 i 1990.

W całym okresie, dla którego było możliwe odniesienie obydwu wymienionych wskaźników do całkowitego ruchu wczasowego w Polsce - uwidacznia się systematyczny spadek udziału FWP (tab. 1). Udział liczby jego wczasowiczów rósł w latach 1956-1960 z 85,9\% do 89,4\%, a później systematycznie malał do 8,4\% w 1990 r. Bardziej dokładny wskaźnik liczby udzielonych noclegów można było obliczyć tylko dla lat 1960-1970 oraz 19761990. Jego najwyższa wartość wystąpiła w 1960 r. (62,4\%), po czym (zapewne) systematycznie malała - do 10,6\% w 1990 r. Jak więc wynika z tab. 1 i rys. 2 - Fundusz dominował w obsłudze polskich wczasowiczów dosyć długo, bo do 1967 r. - do kiedy liczba osób korzystających z obiektów FWP wynosiła ponad $50 \%$, pomimo o wiele mniejszego udziału jego miejsc noclegowych (do 25\%). Świadczy to o dużej popularności FWP do końca lat 60. XX w. (1/3 liczby udzielonych w kraju noclegów), a w związku z tym o stosunkowo dużym wykorzystaniu bazy, co zaznaczyło się jeszcze w 1990 r., kiedy udział FWP w liczbie udzielonych noclegów (10,6\%) oraz jego udział w liczbie osób korzystających $(8,4 \%)$ były nadal wyższe niż udział miejsc noclegowych (6,7\%).

W 2011 r. z obiektów FWP Sp. z o.o. skorzystały 23562 osoby, a w 2012 r. 30950 osób. Średnie wykorzystanie miejsc noclegowych wynosiło w 2011 r. 27,3\% (pokoi - 32,5\%), a w 2012 r. - 35,8\% (pokoi - 41,4\%) (wg danych Zarządu). Wyniki te świadczą o kontynuacji starań o utrzymanie renomy firmy dobrze obsługującej klientów; wystarczy porównać ze średnią krajową, która w 2010 r. równała się: dla obiektów hotelowych 31,9\%, a dla pozostałych obiektów 36,9\% (Rocznik statystyczny... 2012). 


\section{Podsumowanie}

W okresie funkcjonowania FWP zachodziły zmiany jego statusu, najpierw w 1957 r. z głównego ośrodka dyspozycyjnego spadł do rangi jednego z wielu organizatorów wczasów (zakładów pracy), a po 1997 r. - do, co prawda nadal sieciowej, ale już niewiele znaczącej, w porównaniu z przeszłością, spółki organizującej pobyty wczasowo-turystyczne.

Dokładna analiza danych dla kolejnych lat, z których (z powodu ograniczeń edytorskich) tylko część zamieszczono w tab. 1 oraz na rys. 1 i 2 , prowadzi do syntezy na temat zmian infrastruktury i ruchu wczasowiczów FWP; w poszczególnych okresach miały one następujący charakter:

lata 1949-1958 - rozwój chwiejny;

lata 1959-1968 - rozwój wyrazisty;

lata 1969-1978 - stopniowy regres;

lata 1979-1990 - totalny regres.

Opracowanie naukowe Z. PRONIEWICZA i W. SOSZYŃSKIEGO (1959), które przygotowano na 10. rocznicę działalności FWP, pozwoliło przyczynić się do udoskonalenia jego strategii, co uwidoczniło się w okresie prosperity w drugim 10-leciu. Warto tu uwzględnić zmiany, które są mniej wymierne, ale istotne z punktu widzenia rozwoju społecznego, ponieważ dotyczyły troski o:

1) warunki wypoczynku pod względem bezpieczeństwa i wyposażenia budynków (w pierwszym 10-leciu działalności poddano gruntownemu remontowi 855 budynków z 28 tys. miejsc noclegowych (PIECHUCKI 1980), a w okresie 1961-1966 r. remonty zrealizowano w 354 budynkach dysponujących łącznie 10131 miejscami; przeciętnie w roku remontowano 59 budynków. Było to wykonalne ze względu na to, że Fundusz posiadał 10 własnych brygad budowlano-remontowych, w których pracowało 1300 osób (Zwiazkowe... 1967);

2) poziom kadry (o perspektywicznym podejściu do tej sprawy świadczy fakt, że tylko w jednym - 1977 r. zorganizowano 131 kursów doskonalenia zawodowego dla 3,6 tys. pracowników) (HERTRICH-WOLAŃSKI 1980);

3) popularyzację wzorców wypoczynku; na potwierdzenie systematycznie rosnącej w latach 1961-1965 skali upowszechniania kultury, sportu i turystyki wśród wczasowiczów FWP - niech posłuży przytoczenie liczb imprez oraz ich uczestników: artystycznych i oświatowych - od 6,5 tys. dla 560 tys. do 22,8 tys. dla $1,5 \mathrm{mln}$; sportowych - od 3,4 tys. dla 69,7 tys. do 8,2 tys. dla 195,5 tys.; turystycznych - od 13,6 tys. dla 637,2 tys. do 18,6 tys. 
dla 891,3 tys.; o pozytywnej reakcji wczasowiczów na ofertę kulturalną najlepiej świadczy fakt, że w biblioteczkach w domach wczasowych w latach 1961-1965 liczba wypożyczeń wzrosła z prawie 142 tys. do ponad 417 tys. książek (Związkowe... 1967);

4) wczasy lecznicze w 22 współpracujących uzdrowiskach, w 75 domach wczasowych oraz w 7 własnych sanatoriach (łącznie 9063 miejsca noclegowe) (Zwiazkowe... 1967).

Lektura starych opracowań i analiza danych statystycznych dają podstawy do tego, aby potwierdzić, że nadrzędnym celem działania władz FWP były interesy świata pracy (organizacja wypoczynku, zapewnienie regeneracji sił psycho-fizycznych poprzez lokalizację w bodźcowym klimacie, urozmaicone posiłki, opiekę lekarską). Warto powtórzyć za B. PIECHUCKIM (1980, s. 135), że FWP rozbudził potrzeby na zorganizowane formy wypoczynku i - co jeszcze istotniejsze - uczył wypoczywać; takie przynajmniej były założenia, a pojedyncze przypadki odejścia od zalecanych wzorców nie mogą umniejszać wyżej określonych zasług Funduszu.

Dowodem na autentyczność w dbaniu o to, aby jak najwięcej ludzi pracy skorzystało z urlopów, było zapewnienie ulg w odpłatności za nie. Dane potrzebne do obliczenia udziału osób, które skorzystały z wszelkiego wymiaru ulg podano w rocznikach statystycznych dla lat 1950-1970 i dla roku 1973. Najwyższe odsetki osób, które skorzystały z wczasów ulgowych wynosiły: 92,5\% (w 1956 r.) i 90,6\% (w 1961 r.). Warto dodać, że w całym uwzględnionym okresie udziały te nie zeszły poniżej $80 \%$ (tylko dla 7 spośród 22 lat - spadły poniżej $85 \%$ ). Koniecznie trzeba wspomnieć o tym, że FWP zabiegał o systematyczny wzrost udziału robotników wśród wczasowiczów; w 1949 r. wynosił on 34\%, wzrósł do 42,1\% w 1953 r., następnie spadł do 27,3\% w 1956 r., a potem znowu wzrósł do 44,4\% w 1965 r. Każdy spadek tego udziału był skutkiem odchodzenia od preferencji dla robotników w procedurach rozdzielnictwa (JAROSZ 2001, s. 483).

FWP od samego początku zgodnie z deklaracjami władz stanowił ,jeden z najważniejszych pionów w systemie turystyki socjalnej". Wtedy istniało wiele małych zakładów pracy, których nie było stać na własny ośrodek wypoczynkowy, więc FWP dla ich pracowników był jedynym sposobem na dostęp do wczasów ulgowych. FWP-owskie wczasy pracownicze weszły na stałe do obyczaju ludzi pracy w Polsce, stanowiąc prawdziwy dorobek ustroju socjalistycznego (LIBICKI 1980, s. 48-70).

W sytuacji obniżania się udziału Polaków w wyjazdach na wypoczynek wysiłki władz powinny zmierzać ku upowszechnieniu wyjazdów pracow- 
ników małych firm, które dominują nie tylko pod względem ich liczby, ale również zatrudnienia czynnych zawodowo. Firma, która w swej nazwie podkreśla nawiązanie do chlubnej przeszłości, może i powinna zabiegać u władz o taką formułę działania, aby postawić na obsługę osób pracujących, emerytów, rencistów, którzy zastaliby $\mathrm{w}$ domach wczasowych warunki gwarantujące racjonalne spędzenie urlopu (dieta, ruch, krajoznawstwo, rozrywka, a zarazem cisza nocna).

Współcześnie, w związku ze wzrostem automatyzmu w pracy i konsumpcjonizmu propagowanego przez media, nie mniej niż w przeszłości potrzebne jest uczenie efektywnego wypoczynku ludzi intensywnie pracujących. Zmiana statusu FWP nie powinna oznaczać zarzucenia prymatu ludzi zatrudnionych w (dominujących przecież obecnie) małych firmach. Spółce tej powinno zależeć na kontynuacji społecznej aprobaty swej działalności, tak jak w czasach, kiedy zysk nie stanowił jej kryterium wiodącego, tak jak to w odniesieniu do FWP określił B. LIBICKI (1980, s. 49).

Reasumując należy stwierdzić, że przyczyną zasadniczej zmiany - zmiany statusu FWP, która pociągnęła za sobą zmiany w wielkości jego bazy noclegowej i ruchu wczasowego, było odejście od ideologii ustroju socjalistycznego, w którym zakładano prymat ludzi pracy i wynikającą z tego troskę o zabezpieczenie im warunków do wypoczynku.

\section{BIBLIOGRAFIA}

HERTRICH-WOLEŃSKI W., 1979, Kształcenie i doskonalenie kadr dla potrzeb wczasów pracowniczych, [w:] 30 lat działalności Funduszu Wczasów Pracowniczych 1949-1979. Osiąnięcia i perspektywy. Materiały z sympozjum naukowego, Spała 22-24 II 1979, Instytut Wydawniczy CRZZ, Warszawa.

Informacja o wynikach kontroli zarządzania majątkiem byłego Funduszu Wczasów Pracowniczych i jego prywatyzacji, 2004, Najwyższa Izba Kontroli, Departament Gospodarki, Skarbu Państwa i Prywatyzacji.

Jarosz D., 2001, Robotnicy, robotnice i Fundusz Wczasów Pracowniczych w Polsce (do 1956 r.), [w:] A. Żarnowska, A. Szwarc A. (red.), Kobieta i kultura czasu wolnego, t. VII, Wyd. DiG, Warszawa.

JAROSZ D., 2003, Masy pracujace przede wszystkim. Organizacja wypoczynku w Polsce 1945-1956, Akademia Świętokrzyska, Kielce.

Konstytucja Polskiej Rzeczpospolitej Ludowej uchwalona przez Sejm Ustawodawczy w dniu 22 lipca 1952 r., 1989, Książka i Wiedza, Warszawa.

KulCZYCKI Z., 1970, Zarys historii turystyki w Polsce, Sport i Turystyka, Warszawa. 
LiBicKi B., 1980, Turystyka socjalna w Polsce, [w:] 30 lat działalności Funduszu Wczasów Pracowniczych 1949-1979. Osiagnięcia i perspektywy. Materiaty z sympozjum naukowego, Spała 22-24 II 1979, Instytut Wydawniczy CRZZ, Warszawa.

OKRASA R., 1976, Wczasy pracownicze w latach 1972-1976, Instytut Wydawniczy CRZZ (FWP), Warszawa.

OKRASA R., 1980, Ewolucja form organizacyjnych Funduszu Wczasów Pracowniczych CRZZ w 30-letnim okresie jego działalności, [w:] 30 lat działalności Funduszu Wczasów Pracowniczych 1949-1979. Osiagnięcia i perspektywy. Materiały z sympozjum naukowego Spała 22-24 II 1979 r., Instytut Wydawniczy CRZZ, Warszawa.

PIECHUCKI B., 1980, Kierunki działalności FWP w latach 1949-1978, [w:] 30 lat działalności Funduszu Wczasów Pracowniczych 1949-1979. Osiagnięcia i perspektywy. Materiały z sympozjum naukowego, Spata 22-24 II 1979 r., Instytut Wydawniczy CRZZ, Warszawa.

PISARSKA B., 2011, Rola wypoczynku socjalnego w Polsce podczas dekady 1970-1980 w świetle literatury, [w:] K. Rybiński (red.), Dekada Gierka. Wnioski dla obecnego okresu modernizacji Polski, Uczelnia Vistula, Warszawa.

PRONIEWICZ Z., SOSZYŃSKI W., 1959, Dziesięć lat FWP: 1949-1958 w liczbach i wykresach, FWP CRZZ, Warszawa.

Roczniki statystyczne za lata: 1950-91, 2012, GUS, Warszawa.

Statystyka turystyki. 1950-1966, 1967, „Studia i Prace Statystyczne”, 7, GUS, Warszawa.

Turystyka. 1973, „Statystyka Polski”, 5, GUS, Warszawa.

Zwiazkowe wczasy pracownicze w latach 1961-1966, 1967, FWP CRZZ, Wrocław. 